\title{
The Humanities under fire?
}

\section{Rik Pinxten}

\section{Ghent University, Belgium.}

\section{The problem:}

Science is not a divine or otherwise context-free phenomenon. Richard Feynman (1999) related on several occasions how during the Second World War he and his fellow-physicists were confronted with the question whether they should collaborate with the USA at war in order to develop the first atomic bomb, or whether they could afford not to engage themselves in that project. With a path breaking $\mathrm{PhD}$ at the age of twenty five he agreed to go and work in Los Alamos. He was and is considered to be an extremely free thinking and independent sort of researcher in the highest category of excellence (who was granted a Nobel prize for work in theoretical physics).

At the time of Newton most scientists were well to do people, who did not need to bother about survival. Their involvement in science came down to pure interest, pleasure and prestige, and was not or to a much lesser extent concerned with earning a living. In the contemporary world, almost all scientists are hired by universities to teach and do research, by government agencies to do government-driven research, or by private laboratories and industries to either devise or implement patent-research. Practically all of them are dependent on the job to earn their living. In other words, the question is relevant to what extent the wage-earner status of the contemporary scientist impacts on her or his freedom of mind and hence on the freedom of scientific research in itself. Also, at the time of Newton hundreds of learned men busied themselves with scientific research. Today, millions of women and men are earning a salary doing the research as their work. Even more importantly, since the time of Archimedes and again that of Da Vinci, some concepts and results from the natural sciences were put to use by rulers and warriors to enhance their chances in warfare. Today, both military and civil industrial success depend to a large extent on the proficiency of scientific research. So, scientists have become wage earners in a society where science and technology have great importance for the wealth and power of a country or a region. It is important to consider the possible impact of these social and political shifts on the nature and the constraints of the scientific endeavour. According to some analysts 
mentioned in this contribution, a new shift is taking place in the present era: the 'corporatization of science' (see below). Again, we need to reflect on the impact of such a change on research organization and even on the nature of science.

In the past century we have witnessed a gradual (and after the Second World War a fast) growth of universities and of research funding agencies. In the USA this led to a tremendous deployment of two separate types of universities: a private sector (with elite universities as the exemplary cases) and a public system (with excellent centres in some states or cities -e.g., California, and second rate universities in many states). In Europe the university system is primarily a public system, and several important or general private universities have a religious denomination but are factually subsidized by the state or the city. Hence, the influence of political rulers on the development of the university and scientific research arena has been substantial.

However, over the same period, the economic development of the USA and Europe has been absolutely unprecedented. Large parts of the rest of the world have been colonized up to the ' 60 s of the past century, and are held in alliances with the former colonial rulers until today. Granted that these alliances are not easy today (cf. the shifting relationships between the USA and Latin America, or the explicit refusal of the EPAS by African countries vis-à-vis the EU), but the economic and political dependency is still overwhelming (Fukuda: UNDP report 2004). By whatever measure one wants to estimate the growth of wealth (income, consumer capacity, health services, education level), the general trend decidedly is that in the rich countries of what we call 'the West' the past decades showed a tremendous boom in life expectancy and in consumer wealth. Scientific research has come to be looked upon in a different way during that same period: it is not anymore a place of free and unmitigated investigation into the wonders of nature and humans, of minds and cultures. Rather, it became a source of power, of opportunities for business, the military and the political circles.

The student revolts of the '60s opposed the trend to draw intellect into what former President Eisenhower had named the 'Military-industrial complex' (MIC), which had led to the Vietnam war. The state and the economic system, however, needed more brains at the end of the sixties in order to be able to secure the dominance over world markets and political structures, and thus opened up to let a larger amount of students 
into the higher education system. This was then announced as the 'democratisation of education' in several western countries. The student revolts which aimed to overthrow the dominance system of the 'old boys' (rich families, bishops, senior professors, depending on the case of the particular university) should be situated in this complex context (Bourdieu, 1982, Chomsky 1995). With the advent of the first oil crisis in 1973 the uproar was silenced, and the slowing of the economy put an end to the movement of 'democratization of education' as well.

A clear by-product of this student revolt was, however, that the landscape of scientific research was redesigned:

-universities were now built according to the campus model, isolated from the rest of the population in a format of seemingly independent communities. For example, in Belgium the Catholic University of the French speaking community built an entirely new campus as a village (Louvain-la-Neuve) miles removed from any part of normal society. The same can be seen with nearly all 'new' universities or departments of universities, which are located outside of the cities to form campuses in the countryside (Utrecht University, Nijmegen University in The Netherlands, Bochum or Bielefeld in Germany, many of the new universities in southern European countries, and a tremendous amount of the American universities). At best some central offices and promotion buildings are kept in the centre of a town, but the bulk of activity is moved far away from the rest of the population.

- courses were rapidly steered into becoming more uniform (with the Bologna agreements as a 'high point' for the EU in this regard), and controls of all sorts were introduced. Over the past three decades national and transnational controlling systems have been set up: yearly individual controls of all levels of personnel by students, yearly individual controls of personnel by colleagues (deans, computer steered teaching 'guidance', etc.), evaluation rounds of all professors, control procedures for promotion cycles, and so on (Loobuyck et al., 2007). In a few years time, private firms have taken a piece of the controlling and evaluation territory, claiming expertise in these matters on the basis of their marketing and management tradition.

-with this turn towards a rather excessively controlled and regulated treatment of academics a rapidly growing group of bureaucrats emerged and immediately came into power: where professors (and after the '70s professors, other staff and students) had a large saying in what the policy choices in terms of content and of educational procedures would be in a certain school (with a genuine assembly which voted on 
major issues), today the rules for promotion are uniformly and in minute detail defined by the bureaucrats and by self-declared managers of the institute. Often, colleagues who are convinced their innovative power lies in the steering and managing of departments and faculties get themselves elected as deans and as commission presidents. After some years of service they are seen to push on very frequently into other bureaucratic jobs, and to be sitting on councils and boards which decide on ever more rules of management for everybody else. In a few years time they are so far estranged from their own research area that it is difficult for them to get back to their laboratory or department. This is the course of life one might say, except that the rules and regulations they are meanwhile constructing and implementing are all the time more and more imposing and binding for education and research on the floor. In a nutshell, the bureaucratization of education and research has reached such a degree of expansion that it may become counterproductive for research innovation ${ }^{1}$. My point is that indeed the management aspect of spending money is relevant, but that the choice for this or that topic of research, and for this or that approach has to be taken prior to and independent of management considerations. That is, it is bad governance to not decide on preferences and political choices, and to shy away from them in terms of mere policy and management rules. In that move, and this is my first major point, one chooses implicitly and factually for the market and/or for the powerful of the moment to decide for you, and hands over the freedom of choice in education and research to powers one cannot control at all. In my estimation this may yield changes in the nature of scientific research and the status of scientific knowledge. The elementary category mistake (if not cowardice: Chomsky 1970) is that of not distinguishing between policy and politics: politics (in the noble sense) is about the fundamental choices on truth, freedom, relevance and the like, and policy is about organising work and duties in view of the former choices. By exclusively stressing policy the bureaucratisation of education and research kills the arena for the important and free choices of a society. Or, more realistically, it will leave this arena to the external powers who want to control and steer research and the education of the minds for their own private benefits or political aims. This is in profound disagreement with democracy in my understanding, and will only allow for hegemonic policies and antidemocratic

\footnotetext{
${ }^{1}$ In a small quest I launched (through the cover of an interest group promoting 'free research') on these issues to Chancellors and the Minister of education in Flanders, Belgium, the reaction by all but one responsible persons was: 'you may have a point, but we as good managers have to distribute money and hence we need a quantitative measure to decide what to subsidize'.
} 
scheming in the long run. In the following sections I will indicate that such trends and tendencies may already become dominant now.

\section{Cold War and the corporatization of the Humanities:}

a-In an intriguing collection of essays (Chomsky, 1995) a set of leading authors in the Humanities from the USA have brought together information on the ways the military and the secret services have actively influenced the development of several disciplines during the Cold War period. According to the reports on each and every domain of the humanities political, military and secret services personnel often interfered in the promotion of staff and in the launching or development of courses. More often than not these attacks on academic freedom were subliminal in nature, and sometimes led to harm for the researchers targeted. With the MacCarthy era this is well documented. However, in the book edited by Chomsky it proves to be the case that elaborate processes of interference and intrusion on research agendas and on private careers was much more widespread than that, and that such processes continued all the way upto the fall of the Berlin Wall (1989, marking the official end of the Cold War period). History, cultural studies, anthropology, literature and linguistic studies, and philosophy and religious studies were systematically screened and 'coached' by these forces for decades on end. The scope and depth of their impact only became clear when the Chomsky-volume finally got published. For example, Chomsky himself was targeted and harmed in a double scenario: on the one hand, his access to funding was diminished deliberately, and colleagues were found ready to write negative rumourlike criticisms on the quality of his linguistic work. This started when he began to publish highly critical analyses on political issues.

b- In the period after the fall of the Berlin Wall and the implosion of the Soviet Union, a new type of constraining and 'coaching' seems to be emerging: corporatization and the open sponsoring of research in the humanities through secret services.

In a remarkable series on 'Political economy of academia', launched by the newsletter of the largest professional organization in the field of anthropology (Anthropology News, 2008), the famous Chicago anthropologist Marshall Sahlins speaks out about what is now called 'the corporatization of academia'. His main point of departure is that the notion of scientific research is undergoing drastic changes in the past couple of decades. The notion of disinterested and so-called 'free' research ,- advocated forcibly 
in the early $20^{\text {th }}$ century by T. Veblen in the USA, and several top researchers in Europe (B. Russell, and a series of Nobel laureates but also philosophers such as P. Bourdieu) -, is under attack. Veblen for example, was speaking of 'conflicting regimes of truth' (Sahlins, 2008: 5). Utilitarian or pecuniary issues were not considered to be an argument in the debate on truth or relevance of research choices, at least not in principle. Of course, universities need money: 'but they ought to have an academic policy first and then try to finance it, rather than let finances determine their academic policy.' (idem).

Sahlins tells the story of how an excellent centre of research and teaching such as the University of Chicago, notwithstanding its demonstrable very high status (amount of Nobel prizes, excellent research, and healthy finances) was pushed into 'academic capitalism' since the 1990's by a host of business people who were hired as presidents of the University. With that the University of Chicago followed the trend in the rest of the country; universities are rapidly more and more run like businesses: 'logically and categorically, the university-powers-that-be considered the endowment as a "capital fund" -the increase of which would be the principal goal of a capitalist corporation.' (idem). That is to say, not the furthering of knowledge, the greater understanding of the universe and humankind, let alone the transfer of first class knowledge or the serving of society's interests are the ends towards which endowments are the means on the road to realisation. Rather, capitalizing stocks, investing in terms of big contracts for the sake of the contracts, occupying territory in a market universe become the dominant values and steer decisions. The result 'on the floor', however, is that staff is more and more hired as 'adjunct faculty', who fill in jobs with temporary and partial mandates: 'in the country at large ...some 70 percent of all faculty is adjunct'(idem). That is to say, they are in part time jobs, limited in time, serving a clientele of students who need a particular skill. Their research has to keep them in a position of marketability, not have them grow into an adult scope on their topic of research. They have become wage-labourers, and will not risk becoming intellectuals, to put it sharply. The trustees and managerial personnel have become businessmen, with almost entire careers in administration, control of others, fundraising for the sake of fundraising, and so on.. Another effect of the corporate model for academia, Sahlins states, is that scholars (younger ones to begin with) try to define small and so-called promising new niches all the time, which they try to sell as the unique smart focus or innovating subdiscipline and which hence will secure them a job for a longer time, 
because of the market-value of their proposal. This yields an 'institutional involution' (idem: 6), where the core of disciplinary knowledge is snowed under by sometimes exotic new hype subdisciplines and perspectives en vogue.

Sahlins asks the question in his profound contribution to the debate whether corporate logic in research and academia is supplanting the older research perspective of 'free research', openness to innovation from fundamental research and systematic criticism (e.g. R. Merton's views, as exemplified in most National Science Foundations): what is research becoming? Is the corporate organisation format beneficial or harmful for the future of research and of knowledge? Given the importance of knowledge for the wealth of regions these days (even more so in a knowledge society), how should we evaluate at the deeper level (not at that of mere managerial or policy issues) the sense, the value or the danger in this almost silent take over of academia by corporate business? Is knowledge and the development of progress in knowledge to be compared with the rather exotic unlimited games of investment and plunder of shares and stock market bonds which we witness today, and which are apparently convincingly argued for by the managers of this system? Is it merely conservative to ask the question whether the managerial views and practices may be more harmful than foreseen, because knowledge and hence longer term and stronger impact on reality is intrinsically different from bonds, shares and game theoretical schemes? What has the corporate world to show us in terms of longer term successes which benefit the whole of society? And finally, from a democratic perspective on society and its scientific organizations: who decides on all these questions and where and when were they openly discussed by scientists and/or by civil society? These questions should be asked and debated about in an open political discussion in a democratic society before we would let the managers dictate the constraints, but also the rules of the game the way it is happening for over a decade now. So, without offering a definite answer or picking a certain position, I side with Sahlins that we have to try and assess the impact on this way of thinking about research and knowledge before we start implementing the business and management logic, and hence potentially kill the bird instead of having it fly better and faster and with more revenue. That debate, however, has not taken place. Instead, a sort of blind race in the name of the rules of the market and of the manager is underway, it seems to me. 
c- Two instruments, which are beneficial to corporatization have been growing exponentially over the past decades: the measuring rod of the citation system, and the open funding of research by multinational corporations and by secret services. c-1- The citation industry. For some time a private group (Thomson, USA) developed a measuring system for scientific recognition: the ISI (International Science Index). The system counts the amount of citations a researcher accumilates in a (very) limited set of scientific journals. In that way out of tens of thousands of journals in hundreds of languages a very small sample was composed to form a manageable set of almost 8000 journals. The journals are predominantly English language publications (for some fields ranging to more than $90 \%$ ). Citations of an author within these journals are counted by the firm, which publishes the balances regularly. Chapters in books or books in themselves are not included. Hence, a researcher's output is exclusively tracked in this small basket of journals. Given the fact that they are overwhelmingly English language journals and that books and book chapters are not involved in the process, the instrument of ISI is debatable for the Humanities, to say the least. Indeed, the Humanities and Social Sciences study over 4000 living cultures and some 6000 genuine languages in the world, and it is no secret that the Anglosaxon mirror image, if at all relevant or interesting for over $80 \%$ of the world's non-English speaking population, is not necessarily a priority for them in policy or community building decisions. For example, the basket has two English language journals on Taoism, and none at all in Chinese, nor in another relevant language. The reason is most probably that the cost of doing the counting job in a host of other languages would be too high for a commercial enterprise, and maybe that the selling of the ISI journals and publications in other languages would be too risky. The same default can be pointed at for medicinal research on Africa, which is not deemed financially rewarding by the large pharmaceutical firms, which sponsor medical research and get patents from it. Here the reason is demonstrably that Africa will not be able to buy the products, so why would one bother mapping research which is primarily relevant for this part of the world (e.g. malaria studies)? The question should be raised then whether such a market logic can at all be the (factual) basis for the construction of a measuring system for science and knowledge of humankind. How can one justify scientific quality in terms of the amount of money that will be earned by the firm which sells the results of the measuring procedure? How can any sort of objectivity be reached by having the market play? Surely, when markets would be genuinely free, this issue could be 
debated seriously. But continuing publications on growing poverty and durable inequality in the world tell us that such freedom is a fiction (Sen, 2000; Fukuda, 2004). Moreover, in the short existence of the ISI it has become clear how journals engage in a competition on this new 'market' in order to get most attention and impose themselves in a ranking system (the 'impact factor' ranking). Very soon institutes and research groups engaged in the organization of output in order to have high visibility and ranking within the ISI system: by adapting to the rule of the market here, one can reach a 'high number'. When sponsors and governments started using the ISI rankings as a conditional criterion for promotion and for sponsoring of research, a genuine race for the numbers started, which reshaped the presumably 'clever' researchers or research centres into little enterprises concerned with their ISI-returns. We know now that all sorts of tricks can be and are used to boost numbers. We also know that neither relevance of the research, nor intrinsically epistemological choices dominate here: the ranking is guiding the game. Also, by disqualifying in fact (i.e. in view of subsidies and career) books and book chapters, a deep change towards a 'hit and run' market mentality is taking shape. The use of the ISI scores of scholars in important decisions on promotion for jobs and on funding for projects is a clear instance of policy thinking, which occasions at the same time a submission of the scientific world to the political choices of (a private firm in) one country of the world. I called this elsewhere an imperialism of knowledge (Pinxten, 2007).

c-2. Mi5 and CIA present themselves openly as sponsors for research in the Humanities since 2005. In open advertisements in both the British and the American professional journals of anthropology these two secret services offer jobs to those young scholars and professors who want to go and study terrorism in some part of the world. Of course, some debate emerged (Price, 2005), but the fact that these sponsors will own and use the data according to their choice, did not arouse major protest. Indeed, some scholars objected that we have had 'bad experiences' with intrusions by secret services in the past, but others stated that they would go for the money and did not care about the ethical issues. The simple effect that scientific research is thus clearly and openly invaded by organisms which cannot by their nature have an open communication and interaction with citizens (let alone with the subjects under study in anthropology) changes the nature of the research: once more, the researcher is reduced to an instrument one more step, taking leave of the responsibility of his results vis-àvis his subjects and of humanity at large in a dramatic way. 


\section{Conclusion.}

Whatever preferences or ideological and cultural tastes one might have, I want to make first and foremost the point that scientific knowledge seems to be changing 'in nature' or to its core by such developments. It is not simply market or control mechanisms which are added on to the reach and the working of free minds. It looks like the very core business and the mastering of knowledge are shifting toward a new definition. One should wonder whether this is for good or for worse. That is, one may ask the question who is deciding on what science is and what type of science is needed, when scientists themselves seem to have given the right to decide on such questions out of hand. Secondly, it certainly does not look as if society or a representative and democratically accountable body of it is in power to claim and execute this right. When this analysis has some validity I think it is high time to put these questions on the table if one still believes in the power of scientific research. The courage to do so will be substantial: one will probably need to take back the power which has slipped inadvertently in the hands of corporations and of their bureaucrat servants. One will also need to trust scientists again, and to do away with the 'scholastic' turn of the policy makers who control and evaluate quantitatively on formal issues only rather than debate and choose in open arenas for quality.

References.

Bourdieu, P. (1982) : La distinction. Paris: Editions de Minuit.

Chomsky, N. (1970) : The New Mandarins. New York: Basic Books.

Chomsky, N. (1995,ed.): The Humanities in the USA during the Cold War. New York. Feynman, R. (1999): The pleasure of finding things out. New York: Perseus Publishing.

Fukuda, (2004,ed.):

Loobuyck, P. (2007, ed.): Welke Universiteit wensen wij (niet)? Gent: Academia Press.

Pinxten, R. (2007): De Strepen van de Zebra. Antwerp: Houtekiet.

Price, H. (2005): ‘America the Ambivalent.' Anthropology Today: 21, 5: 1-2.

Sahlins, M. (2008): 'The corporatization of academia.' Anthropology Newsletter, February. 
Sen, A. (2000) Rationality and Freedom. Cambdrige, Mass.: Harvard University Press. 